\title{
Nutrition Intensity in Ternary Diagrams Interpretation for Some Ornamental Species Cultivated on Organic Substrate with Increased Biological Activity
}

\author{
Roxana Maria MADJAR ${ }^{1}$, Gina VASILE SCĂET,EANU ${ }^{1}$, Mircea MIHALACHE ${ }^{1}$, \\ Cătălina CĂLIN², Valentin Sebastian DAN ${ }^{3}$, Adrian PETICILA ${ }^{4 *}$ \\ ${ }^{1}$ University of Agronomic Sciences and Veterinary Medicine, Faculty of Agriculture, 59 Mărăști Blvd., District 1, 011464 , \\ Bucharest,Romania; rmadjar@yahoo.com; ginavasile2000@yahoo.com; mihalachemircea@yahoo.com \\ ${ }^{2}$ Petroleum-Gas University of Ploiesti, Faculty of Petroleum Refining and Petrochemistry, 39 Blvd. Bucureşti, 100680, \\ Ploiesti,Romania; catalina.calin20@yahoo.com \\ ${ }^{3}$ University of Agricultural Sciences and Veterinary Medicine, 3-5 Manastur St., Cluj-Napoca, Romania; dan.valentin@gmail.com \\ ${ }^{4}$ University of Agronomic Sciences and Veterinary Medicine, Faculty of Horticulture, 59 Mărăş̧ti Blvd., District 1, 011464, \\ Bucharest,Romania; apeticila@yahoo.com ( ${ }^{*}$ corresponding author)
}

\begin{abstract}
Nowadays, many biodegradable organic wastes no longer need to represent an environmental hazard and as a consequence, they could be recycled to obtain horticultural substrates. An experiment was conducted on two deciduous (Tamarix tetrandra, Ligustrum ovalifolium 'Aureum') and two coniferous species (Chamaecyparis pisifera 'Boulevard', Chamaecyparis lawsoniana 'Stardust') grown on a soil mixture of forestry compost, leaves compost, peat and grape marc compost. The aim of the research was to investigate the response to fertilization and to obtain valuable information regarding absorption rate of nutritive elements during vegetation. Nitrogen data show a lowering of its nutritive equilibrium point towards autumn in the leaves of deciduous shrubs species. Resorption of nutrients before leaves fall occurs due to conservation process in woody plants with deciduous leaves. In the case of coniferous species the lowering of nitrogen content is less intense. The monthly fertilization with Coïc solution indicates no influence on nitrogen metabolism of this species. The exception was on Ligustrum with differences between nitrogen content in fertilized and unfertilized plants. The phosphorus nutritive equilibrium point reveals a decrease during the summer months (July - August), the species presenting the lowest values in this period and the cause of this behaviour was the plants adaptation to high temperature and low humidity. Potassium nutritive equilibrium data indicates small differences in the unfertilized plants in comparison with those fertilized in all species. The novelty of the research is represented by the ternary diagrams N-P-K that were constructed, interpreted and reported for dendrologic species.
\end{abstract}

Keywords: dendrologic species, N-P-K diagrams, substrate, grape marc compost

\section{Introduction}

In European Union countries, where recycling and reintroduction of numerous waste vegetal circuits is a widespread activity, compost marketing is regulated by several laws. Composts for horticultural market are labelled mandatory wearing explanation of the origin, the components of the substrate, as any natural or synthetic materials, organic or mineral elements that may alter the mechanical, physical, chemical or biological character of the substrate. Feasibility of mixtures of substrates is virtually numerous, but substrates characterized by phytotoxicity, instability, high cost or limited availability are constantly rejected.

For intensive horticulture is mandatory to assure maximum quality and to use environmental friendly methods. A literature survey concerning different substrates used in horticulture revealed that until at a certain moment, the cultures on growing media have been carried out with a limited number of substrates (peat, rockwool, glasswool, perlite, vermiculite, charcoal chips) (Olle et al., 2012; Restrepo et al., 2013; Santiago et al., 1989).

Lately, people are keen on the research and development of ecologically friendly substrates, which recently have been proven as a viable alternative to other traditional methods.

Nowadays, there is a growing interest in the exploitation of the residues generated by wine industry. Grape marc (waste skins, seeds and stalks), a valuable waste product in wine producing regions, is generated from the crushing, draining and pressing stages of the wine production, and contains approximately $8 \%$ seeds, $10 \%$ stems, $25 \%$ skins, 57\% pulp (Laurenson et al., 2012). There are researches that 
present the effects of composted grape marc as substrate for ornamental plants (Chen et al., 1988), vegetables (Baran et al., 2001; Carmona et al., 2012; Leoni et al., 1992). Therefore, identifying new materials suitable to obtain substrates for horticultural purposes is an important requirement. Grape marc composts possess chemical particularities that are responsible for fertility improvement (high contents of potassium and organic matter and significant contents of nitrogen and phosphorus) (Bustamante et al., 2005, 2007, 2010), but there are some environmental problems related with its acidic character, high content of phenolic compounds and with phytotoxic and antimicrobial effects (Carmona et al., 2012). Sometimes, substrates used for different ornamental species are insufficiently rich in nutrients. Providing ornamental plant nutrients can be handled by applying the fertilizer in the form of liquid or solid substrate.

Having in view that many biodegradable organic wastes can be recycled to ensure sustainability, this being an inexpensive alternative to obtain horticulture substrates, an experiment was designed and focused on four dendrologic species grown on a substrate composed of forestry compost, leaves compost, peat and grape marc compost, with the aim to investigate the plants response to fertilization and to obtain ternary diagrams (N-P-K) that will provide information suitable to interpret species particularities, the absorption rate of nutritive elements during vegetation period.

\section{Materials and methods}

\section{Substrate composition and plant material}

The experiments were set up at the greenhouse from University of Agronomic Sciences and Veterinary Medicine Bucharest. Four dendrologic species were planted in vegetation pots (8 L capacity) that contained substrate formulated according to the recipe described below.

The organic materials used for the substrate composition were forestry compost (FC), leaves compost (LC), peat (P) and grape marc compost (GM) according to volumetric ratio FC: LC: P: GM = 1:1:1:0.5. The disinfection of the substrate components for pathogen destruction was made at $55^{\circ} \mathrm{C}$.

There were analyzed two deciduous species (Tamarix tetrandra, Ligustrum ovalifolium 'Aureum') and two coniferous species (Chamaecyparis pisifera 'Boulevard', Chamaecyparis lawsoniana 'Stardust'). During vegetation period it were performed the cutting of the branches to uniform the plants (in the middle of May), watering, mechanic weed control and application of phytosanitary treatments. In the experiments, it was used Coï acidophile solution (Davidescu et al., 2001) as source of macro- and microelements.

In June, the substrate was characterized from agrochemical point of view and it has been applied as the first fertilization treatment with Coïc acidophile solution, for a part from potted plants. At 30 days (July) the substrate was analyzed after fertilizer has been applied, the operation being repeated another 2 times (August, September).
Substrate agrochemical characterization and plant analysis

The substrate analyses were performed at the beginning of the experiment. The agrochemical characterization of the substrate was made by assessment of $\mathrm{pH}, \mathrm{EC}$ (electrical conductivity), soluble forms (1:10, $\mathrm{v} / \mathrm{v}$ ratio) as nitrate, ammonium, phosphorus, potassium and sodium (Tab. 1). Also, mobile phosphorus and exchangeable forms of main cations $\left(\mathrm{K}^{+}, \mathrm{Na}^{+}, \mathrm{Ca}^{+2}, \mathrm{Mg}^{+2}\right)$ were determined in $\mathrm{CH}_{3} \mathrm{COONH}_{4} 0.5 \mathrm{M}, \mathrm{pH}=4.65,1: 3 \mathrm{v} / \mathrm{v}$ ratio (Tab. 2).

During the experiment at four moments (M1 - June, M2 - July, M3 - August, M4 - September) in order to establish the absorption rate of nutritive ions, for each plant species it were achieved total forms of nitrogen, phosphorus and potassium, using acknowledged methods (see Analytical methods and techniques section) (Tab. 3).

The nutritive equilibrium is given by the ratio of each element $(\mathrm{N}, \mathrm{P}, \mathrm{K})$ expressed as percent against the sum of their concentrations, as it is presented below:

$$
\begin{aligned}
& \mathrm{En}_{\mathrm{N}}=\frac{\% \mathrm{~N}}{\sum \mathrm{N}, \mathrm{P}, \mathrm{K}} \cdot 100 ; \mathrm{En}_{\mathrm{P}}=\frac{\% \mathrm{P}}{\sum \mathrm{N}, \mathrm{P}, \mathrm{K}} \cdot 100 ; \\
& \mathrm{En}_{\mathrm{K}}=\frac{\% \mathrm{~K}}{\sum \mathrm{N}, \mathrm{P}, \mathrm{K}} \cdot 100 .
\end{aligned}
$$

\section{Biotic and enzymatic characterization of substrates}

The biotic tests carried out on substrates have investigated the respiration and cellulolytic activity (Dashtaban et al., 2010). Enzymatic tests were based on sugar hydrolysis (saccharase activity) (Balezentiene et al., 2009; Shi et al., 2008), urea hydrolysis (urease activity) (Shi et al., 2008) and phosphorus hydrolysis from organic compounds (phosphatase activity) (Balezentiene et al., 2009; Shi et al., 2008). In addition, catalase activity (Shi et al., 2008) was determined in order to obtain information concerning oxidation processes from substrates.

\section{Analytical methods and techniques}

Analytical grade chemicals were used throughout the study without any further purification. The $\mathrm{pH}$ values were carried out through potentiometric method, meanwhile EC (electrical conductivity) was determined using conductivity method. Soluble and total phosphorus contents were evaluated by spectrophotometric molybdenum blue method. The levels of nitrate and ammonium species were assessed by spectrophotometric means, also using phenoldisulfonic acid and Nessler reagent, respectively. Total form of nitrogen was determined using Kjeldahl method, meanwhile potassium and sodium contents were assessed using atomic emission spectrometry.

Calcium and magnesium concentrations were determined through flame atomic absorption spectrometry (FAAS). Measurements were carried out using a Thermo Scientific AA Spectrometer. Selected wavelengths were $422.7 \mathrm{~nm}$ for calcium and $285.2 \mathrm{~nm}$ for magnesium. The calibration curves for calcium and magnesium are linear for the studied ranges and were plotted by running different concentrations of standard solutions prepared from stock solutions of $1000 \mathrm{mg} / \mathrm{L}$ calcium and magnesium, respectively. 
575

\section{Results and discussions}

\section{Substrate characterization}

The main agrochemical characteristics of the substrates are presented in Tabs. 1 and 2. Also, biotic and enzymatic tests were carried out for substrates and the results are presented in Tab. 3.

Respiration activity indicates the global biological activity of a substrate and the obtained value for this biotic test was $93.36 \mathrm{mg} \mathrm{CO} / 100 \mathrm{~g}$ substrate (d.w.). Cellulolytic potential of the substrate is correlated with organic matter, the latest one representing the substrate for cellulolytic microflora. Catalase and saccharase activities are related with high organic matter content of the substrates. The urease potential of the analyzed substrate is high (662 $\mathrm{mg} \mathrm{NH}_{4}^{+} / 100 \mathrm{~g}$ substrate), this indicating the possibility of ammonia loses through volatilisation.

Phosphatase activity of the substrate is quantified through phosphorus that is released enzymatic and the obtained value is $5.72 \mathrm{mg} \mathrm{P} / 100 \mathrm{~g}$ substrate (d.w.). The increased biological activity is due to the high $\mathrm{C} / \mathrm{N}$ ratio $(20.8-26.85)$ in comparison with humus level (10-12\%), this indicating that organic matter is still decomposing.

\section{Nutritive equilibrium}

The establishment of nutritive equilibrium was done using the method based on the global nutrition calculation, according to experimental analysis performed during the vegetation period. The global nutrition is the sum of N, P, K concentrations (as total forms) expressed as percents from dry matter. The values obtained after plant analysis during vegetation period at certain moments are summarized in $\mathrm{Tab}$. 4.

The interpretation was expressed through ternary diagram N-P-K using a triangular system. For each of the dendrologic specie that were subjects of the experiment, it were constructed ternary diagrams $(\mathrm{N}-\mathrm{P}-\mathrm{K})$ that allowed to interpret the species particularities, the absorption rate of nutritive elements for fertilized and unfertilized variant.

The ternary diagrams with highlighted theoretic nutritive equilibrium obtained for Tamarix tetrandra, Ligustrum ovalifolium 'Aureum', Chamaecyparis pisifera 'Boulevard', Chamaecyparis lawsoniana 'Stardust' represent a new edge concerning nutritive equilibrium of $\mathrm{N}, \mathrm{P}, \mathrm{K}$ for ornamental species. Also, the values for nutritive equilibrium of the same elements after plant analysis were evidenced.

\section{Nutritive equilibrium for Tamarix tetrandra}

The points for nutritive equilibrium resulted for unfertilized variant Tamarix tetrandra describe the equilibrium area with trilinear coordinates for $\mathrm{N}$ between $48.36 \%$ and $61.67 \%$, for phosphorus between $3.91 \%$ and $14.02 \%$ and for potassium between $24.32 \%$ and $40.46 \%$.

The analysis revealed that at the beginning of the vegetation period the nitrogen absorption was higher and decreased as dry matter accumulation increased. The phosphorus absorption is intense at the beginning, and decrease to a third, during vegetation period, so that at the end to increase at values comparable with those recorded at vegetation start stage. Potassium absorption increase slightly during vegetation period as it is shown by the equilibrium points resulted from $\mathrm{En}_{\mathrm{K}}$ coordinates (Fig. 1, a).

Equilibrium points resulted from the variant fertilized with acidophile Coïc solution marks the nutrient equilibrium for species Tamarix tetrandra by a shift of equilibrium in behalf of $\mathrm{N}$ absorption and less intense for $\mathrm{P}$ and $\mathrm{K}$ compared to the unfertilized (control) variant (Fig. 1, a).

\section{Nutritive equilibrium for Ligustrum ovalifolium}

Ligustrum ovalifolium equilibrium points obtained from the unfertilized variant describe the nutritive equilibrium area with trilinear coordinates for $\mathrm{En}_{\mathrm{N}}$ between $41.43 \%$ and $57.13 \%$, for $E n_{P}$ between $3.62 \%$ and $14.38 \%$ and for $E n_{K}$ between $32.87 \%$ and $50.50 \%$. Nitrogen uptake is more intense at the early vegetation stage, then has an equilibrium plateau and finally decreases slightly.

Phosphorus uptake is intense in June and then decreases in July and August about three times; in early September it was observed the increase of the absorption intensity of phosphorus, which exceeds the values recorded at the beginning of the vegetation period.

During the vegetation, potassium absorption is intense and constantly increases, with highest values in July, until it records a slight decline marked by a stable balance at the end of the vegetation stage (Fig. 1, b).

Equilibrium area delimited by equilibrium points in fertilized variants exhibits a constant absorption of phosphorus, significant variation of nitrogen absorption intensity that is intense at the beginning of vegetation stage, but decreases as dry matter accumulate and grows again in the following stages. Potassium absorption intensity shows large increases to a maximum and decreases at the end of the vegetation period.

\section{Nutritive equilibrium for Chamaecyparis pisifera 'Boulevard'}

The equilibrium areas for Chamaecyparis pisifera 'Boulevard' bounded by the equilibrium points resulted after data calculation, presents differences between unfertilized and fertilized variants. It was observed that the uptake of $\mathrm{N}$ was more intense at the early vegetation period for unfertilized variant in comparison with the fertilized one. The absorption intensity values for $\mathrm{P}$ are undifferentiated by fertilization and constant for $\mathrm{K}$ at fertilized variant, meanwhile the unfertilized variant it registered an increasing trend. The coordinates for ternary diagram take values between $46.86 \%$ and $57.75 \%$ for $E_{N}, 4.40 \%$ and $12.49 \%$ for $E_{P}$ and $37.38 \%$ and $46.06 \%$ for $\operatorname{En}_{K}$ (Fig. 1, c).

\section{Nutritive equilibrium for Chamaecyparis lawsoniana 'Stardust'}

The equilibrium areas delimited by the equilibrium points shows that between unfertilized and fertilized variants there are no significant differences for Chamaecyparis lawsoniana 'Stardust'; the areas are almost overlapped, this behavior indicating that fertilization does not influence the absorption of nutritive elements N-P-K. The coordinates for nutritive equilibrium for unfertilized variant (as control), vary between $56.42 \%$ and $72.85 \%$ for $E n_{N}, 5.10 \%$ and $15.32 \%$ for $E n_{P}$ and between $13.05 \%$ and $38.20 \%$ for $E n_{K}$ (Fig. 1, d). 
Tab. 1. The agrochemical characterization (soluble forms) of the substrates with potted plants

\begin{tabular}{lccccccccc}
\hline \multicolumn{1}{c}{ Substrate with potted plants } & $\mathrm{pH}$ & $\begin{array}{c}\mathrm{EC} \\
\mathrm{dS} \cdot \mathrm{m}^{-1}\end{array}$ & $\begin{array}{c}\mathrm{PO}_{4}^{3-} \\
\mathrm{ppm}\end{array}$ & $\begin{array}{c}\mathrm{NO}_{3}{ }^{-} \\
\mathrm{ppm}\end{array}$ & $\begin{array}{c}\mathrm{NH}_{4}^{+} \\
\mathrm{ppm}\end{array}$ & $\begin{array}{c}\mathrm{Ca}^{2+} \\
\mathrm{ppm}\end{array}$ & $\begin{array}{c}\mathrm{Mg}^{2+} \\
\mathrm{ppm}\end{array}$ & $\begin{array}{c}\mathrm{K}^{+} \\
\mathrm{ppm}\end{array}$ & $\begin{array}{c}\mathrm{Na}^{+} \\
\mathrm{ppm}\end{array}$ \\
\hline Tamarix tetrandra & 7.83 & 0.1359 & 22.00 & 0.50 & 25.00 & 112.23 & 13.693 & 140 & 20 \\
Ligustrum ovalifolium 'Aureum' & 8.14 & 0.2687 & 38.40 & trace & 23.00 & 163.24 & 24.604 & 290 & 17 \\
Chamaecyparispisifera 'Boulevard' & 8.03 & 0.1468 & 42.40 & 4.00 & 23.00 & 193.85 & 24.192 & 145 & 11 \\
Chamaecyparis lawsoniana 'Stardust' & 7.80 & 0.1037 & 29.80 & 3.00 & 9.00 & 102.03 & 14.434 & 62 & 20 \\
\hline
\end{tabular}

After chemical plant analysis at moments M1-M4 (June - September), there were obtained results that were compared with limits from literature data (Davidescu et al., 2001). An overview based on the obtained results is detailed in Tab. 5. The studies of nutrition intensity of dendrologic species cultivated in substrate made of leaves compost, forestry compost, peat and grape marc compost (ratio 1: 1: 1: 0.5$)$ reveals significant differences between deciduous (Tamarix tetrandra, Ligustrum ovalifolium 'Aureum') and coniferous species (Chamaecyparis pisifera 'Boulevard', Chamaecyparis lawsoniana 'Stardust'), but not significant differences in applied fertilizers as Coïc solution during vegetation period (June-September) in comparison with unfertilized plants for all studied species.

\section{Discussion}

Ternary diagrams are used in various areas (chemistry, geology, industry, biology, agriculture) and represent graphic tools that permit to evaluate the interaction between systems and the interactions between systems and environment (Almeida et al., 2007; Giannetti et al., 2006, 2013), allow the estimation of nutrients balance in soil (Parent $e t$ al., 2012), visualization of relation among the three humus fractions (Watanabe et al., 1991) or variation of sugar composition in nectars (Herrera et al., 2006). In literature, there is lack of information concerning ternary diagrams correlated with nutritive equilibrium in the case of dendrology species. Notwithstanding, some similar researches have been presented for potato (Thomas, 1938).

The data obtained in this experiment conducted with the aim to evaluate the absorption rate of nutritive elements during vegetation period for different dendrologic species, allowed us to construct ternary diagrams N-P-K. The four studied species belonging to the two different groups of deciduous and coniferous trees, with distinct metabolism and diverse biological particularities, have responded different to the application of fertilizers. Their behaviour after nutritive

Tab. 2. Mobile phosphorus and exchangeable forms of main cations in substrate with potted plants

\begin{tabular}{lccccc}
\hline \multicolumn{1}{c}{ Substrate with potted plants } & $\begin{array}{c}\mathrm{P} \\
(\mathrm{ppm})\end{array}$ & $\begin{array}{c}\mathrm{Ca} \\
(\mathrm{mE} / 100 \mathrm{~g})\end{array}$ & $\begin{array}{c}\mathrm{Mg} \\
(\mathrm{mE} / 100 \mathrm{~g})\end{array}$ & $\begin{array}{c}\mathrm{K} \\
(\mathrm{mE} / 100 \mathrm{~g})\end{array}$ & $\begin{array}{c}\mathrm{Na} \\
(\mathrm{mE} / 100 \mathrm{~g})\end{array}$ \\
\hline Tamarix tetrandra & 262.00 & 59.05 & 2.566 & 0.910 & 0.1413 \\
Ligustrum ovalifolium 'Aureum' & 278.00 & 52.94 & 2.553 & 1.028 & 0.1217 \\
Chamaecyparis pisifera 'Boulevard' & 162.75 & 42.76 & 2.027 & 0.910 & 0.1000 \\
Chamaecyparis lawsoniana 'Stardust' & 290.00 & 54.47 & 2.537 & 0.769 & 0.1300 \\
\hline
\end{tabular}

Tab. 3. Biotic and enzymatic tests developed on substrate

\begin{tabular}{cccccc}
\hline \multicolumn{2}{c}{ Biotic tests } & \multicolumn{4}{c}{ Enzymatic tests } \\
\hline $\begin{array}{c}\text { Respiration activity } \\
(\mathrm{mg} \mathrm{CO} / 2 / 100 \mathrm{~g})\end{array}$ & $\begin{array}{c}\text { Cellulolytic activity } \\
(\mathrm{g} \text { cellulose } /\end{array}$ & $\begin{array}{c}\text { Catalase activity } \\
\left(\mathrm{cm}^{3} \mathrm{O}_{2} /\right.\end{array}$ & $\begin{array}{c}\text { Saccharase activity } \\
(\mathrm{mg} \text { saccharose } /\end{array}$ & $\begin{array}{c}\text { Urease activity } \\
\left(\mathrm{mg} \mathrm{NH}_{4}^{+} /\right.\end{array}$ & $\begin{array}{c}\text { Phosphatase activity } \\
(\mathrm{mg} \mathrm{P} /\end{array}$ \\
\hline 93.36 & $760 \mathrm{~g}$ cotton $)$ & $100 \mathrm{~g})$ & $100 \mathrm{~g})$ & $100 \mathrm{~g})$ & $100 \mathrm{~g})$ \\
\hline
\end{tabular}

Tab. 4. Total forms of nutritive elements after plant analysis

\begin{tabular}{|c|c|c|c|c|c|c|c|c|c|c|c|c|}
\hline \multirow{3}{*}{ Var } & \multicolumn{3}{|c|}{ June } & \multicolumn{3}{|c|}{ July } & \multicolumn{3}{|c|}{ August } & \multicolumn{3}{|c|}{ September } \\
\hline & \multicolumn{12}{|c|}{ Total forms (\%) } \\
\hline & $\mathrm{N}$ & $\mathrm{P}$ & $\mathrm{K}$ & $\mathrm{N}$ & $\mathrm{P}$ & $\mathrm{K}$ & $\mathrm{N}$ & $\mathrm{P}$ & $\mathrm{K}$ & $\mathrm{N}$ & $\mathrm{P}$ & $\mathrm{K}$ \\
\hline $\mathrm{V} 1$ & 4.1850 & 0.952 & 1.65 & 3.2517 & 0.218 & 2.10 & 2.5542 & 0.174 & 1.65 & 2.8686 & 0.663 & 2.40 \\
\hline $\mathrm{V} 2$ & 4.2734 & 0.872 & 1.50 & 3.2223 & 0.244 & 1.95 & 2.6132 & 0.168 & 1.50 & 2.7900 & 0.625 & 2.00 \\
\hline V3 & 3.3893 & 0.593 & 1.95 & 3.1339 & 0.247 & 3.45 & 2.9472 & 0.214 & 2.60 & 2.4265 & 0.844 & 2.60 \\
\hline V4 & 3.1339 & 0.614 & 1.70 & 2.2497 & 0.236 & 3.40 & 2.7212 & 0.235 & 2.65 & 2.6819 & 0.718 & 2.40 \\
\hline V5 & 2.2399 & 0.189 & 1.45 & 2.1514 & 0.191 & 2.00 & 2.3086 & 0.189 & 1.50 & 2.1907 & 0.582 & 1.90 \\
\hline V6 & 2.1908 & 0.171 & 1.60 & 2.2006 & 0.190 & 1.90 & 2.2890 & 0.156 & 1.90 & 2.3784 & 0.560 & 1.95 \\
\hline V7 & 2.7900 & 0.540 & 0.50 & 2.1416 & 0.204 & 1.45 & 2.4953 & 0.204 & 1.30 & 2.3086 & 0.653 & 1.30 \\
\hline V8 & 3.0651 & 0.558 & 0.65 & 2.1907 & 0.200 & 1.50 & 2.5542 & 0.191 & 1.25 & 2.3577 & 0.561 & 1.35 \\
\hline
\end{tabular}

V1 - Tamarix tetrandra (unfertilized); V2 - Tamarix tetrandra (fertilized); V3 - Ligustrum ovalifolium (unfertilized); V4 - Ligustrum ovalifolium (fertilized); V5 Chamaecyparis pisifera 'Boulevard' (unfertilized); V6 - Chamaecyparis pisifera 'Boulevard' (fertilized); V7 - Chamaecyparis lawsoniana 'Stardust' (unfertilized); V8 Chamaecyparis lawsoniana 'Stardust' (fertilized) 
577

Tab. 5. General overview on nutritive equilibrium for ornamental species

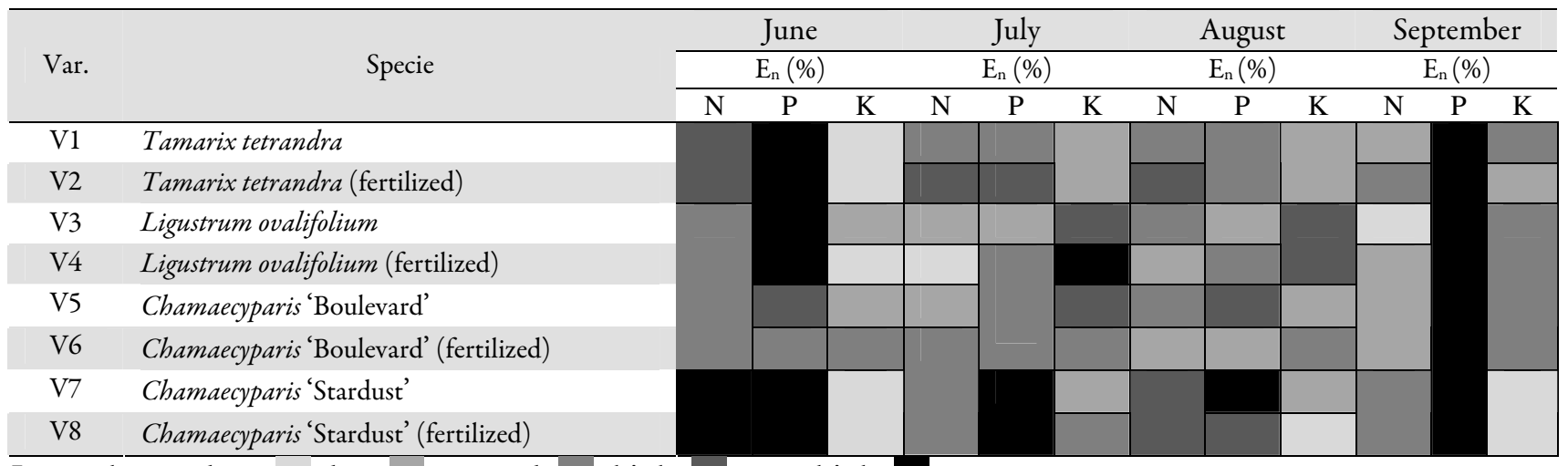

Legend: very low ; low ; normal _ ; high _ very high

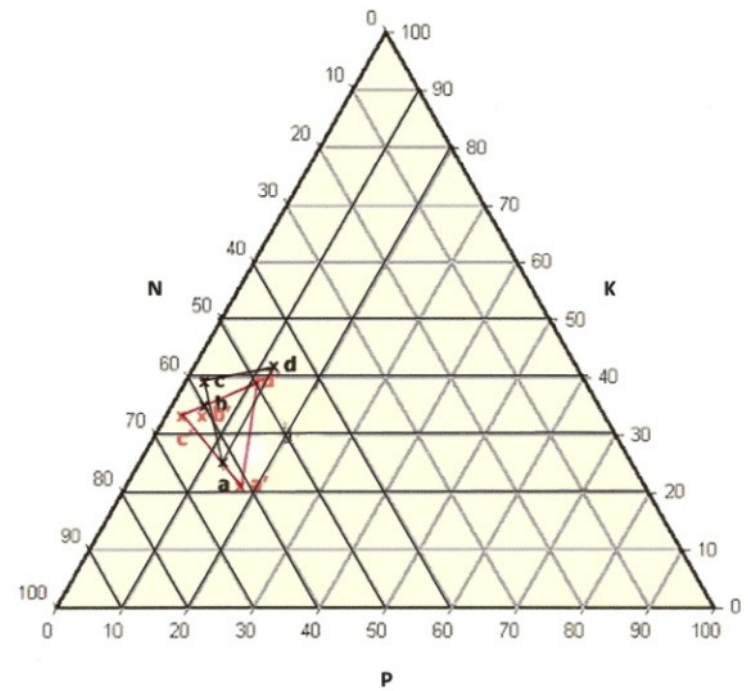

a) Ternary diagram N-P-K for Tamarix tetrandra

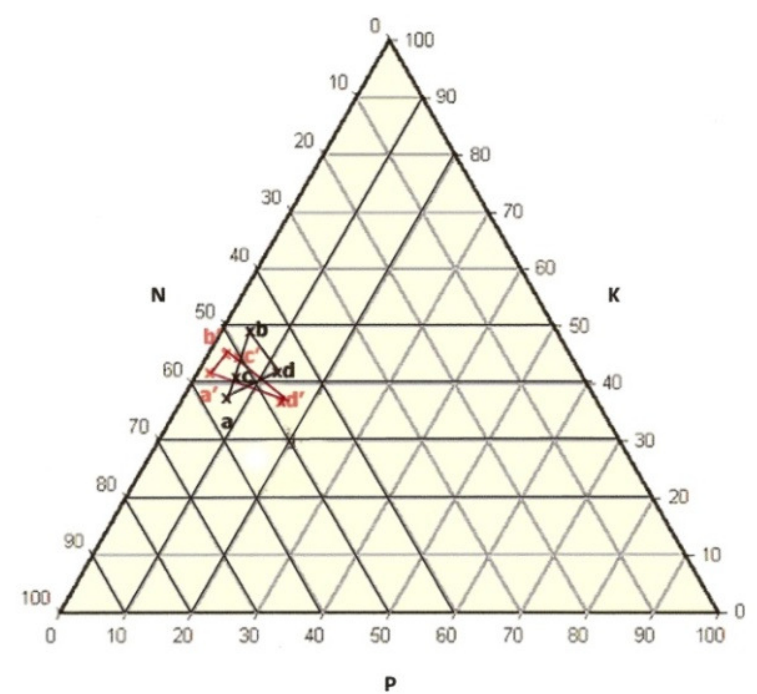

c) Ternary diagram N-P-K for Chamaecyparis pisifera 'Boulevard'

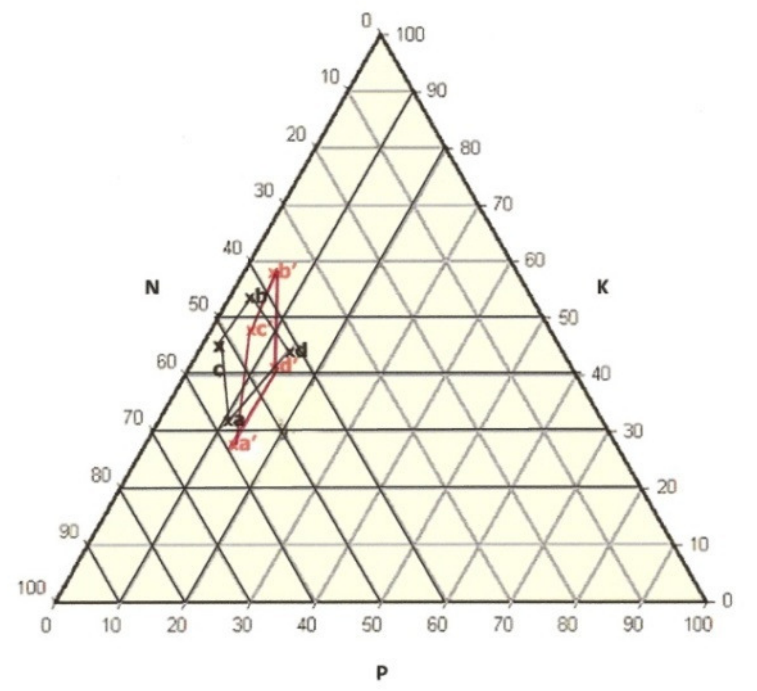

b) Ternary diagram N-P-K for Ligustrum ovalifolium 'Aureum'

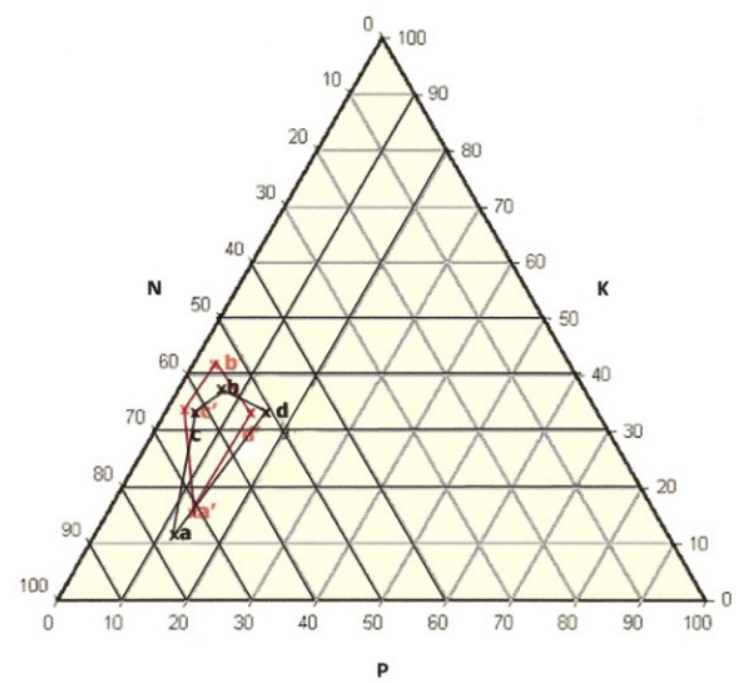

d) Ternary diagram N-P-K for Chamaecyparis lawsoniana 'Stardust'

Fig. 1. Ternary diagram for studied dendrologic species (black line - unfertilized; red line - fertilized) 
solution application on the same substrate is different concerning nutrient absorption capacity, nutrient balance during the vegetation period and the relationship between species, enzyme substrate and biotic indicators of used substrate.

Equilibrium points represented in the ternary diagrams N-P-K resulted from fertilized variant with acidophile Coïc solution, marks the nutrient equilibrium area for specie Tamarix tetrandra by a shift of nutrient balance for the absorption of $\mathrm{N}$ and less intense for $\mathrm{P}$ and $\mathrm{K}$ compared to the control variant.

The equilibrium area delimited by the points of equilibrium for Ligustrum ovalifolium 'Aureum' in the case of fertilized variants present constant absorption of $\mathrm{P}$, large variations of the intensity of $\mathrm{N}$ absorption that is intense at the beginning of the vegetation period and decrease as the dry matter accumulate, then increase again during the rest of the following period. The intensity of $\mathrm{K}$ absorption shows large increases up to a maxima and then decreases at the end of vegetation period.

The equilibrium areas for Chamaecyparis pisifera 'Boulevard' bounded by the equilibrium points resulted after calculation shows differences between unfertilized and fertilized variants with more intense consumption at the beginning of the vegetation period for $\mathrm{N}$ at unfertilized variant in comparison with the fertilized one. The values that describe the intensity of the $\mathrm{P}$ absorption are undifferentiated from fertilization and are constant for $\mathrm{K}$ at fertilized variant, with increasing values for unfertilized variant.

For Chamaecyparis lawsoniana 'Stardust' there is no differences between fertilized and unfertilized plants related with the nutrients absorption, the fertilization leading to an undetectable influence. On the other hand, there is a higher difference of nutritive elements absorption intensity in comparison with Chamaecyparis pisifera 'Boulevard'.

\section{References}

Almeida CMVB, Barrella FA, Giannetti BF (2007). Emergetic ternary diagrams: five examples for application in environmental accounting for decision-making. J Clean Prod 15:63-74.

Balezentiene L, Klimas E (2009). Effect of organic and mineral fertilizers and land management on soil enzyme activities. Agronomy Research 7(1):191-197.

Baran A, Çayci G, Kütük C, Hartmann R (2001). Composted grape marc as growing medium for hypostases (Hypostases phyllostagya). Bioresource Technol 78:103-106.

Bustamante MA, Paredes C, Moral R, Moreno-Caselles J, PerezEspinosa A, Perez-Murcia MD (2005). Use of winery and distillery effluents in agriculture: characterisation of nutrient and hazardous components. Water Sci Technol 51:145-151.

Bustamante MA, Paredes C, Moral R, Moreno-Caselles J, PerezMurcia MD, Perez-Espinosa A, Beral MP (2007). Cocomposting of distillery and winery wastes with sewage sludge. Water Sci Technol 56(2):187-192.

Bustamante MA, Said-Pullicino D, Paredes C, Cecilia JA, Moral $R$ (2010). Influences of winery-distillery waste compost stability and soil type on soil carbon dynamics in amended soils. Waste Manage 30:1966-1975.

Carmona E, Moreno MT, Aviles M, Ordovas J (2012). Use of grape marc compost as a substrate for vegetable seedlings. Sci Hortic-Amsterdam 137:69-74.

Carmona E, Moreno MT, Aviles M, Ordovas J (2012). Composting of wine industry wastes and their use as a substrate for growing soilless ornamental plants. Span J Agric Res 10(2):482-491.

Chen Y, Inbar Y, Hadar Y (1988). Composted agricultural wastes as potting media for ornamental plants. Soil Sci 145(4):298-303.

Dashtaban M, Maki M, Leung KT, Mao C, Qin W (2010). Cellulase activities in biomass conversion: measurement methods and comparison. Crc Cr Rev Biotechn 30(4):302-309.

Davidescu V, Costea G, Madjar R, Stanica F, Caretu G (2001). Substrates of culture (in Romanian). Ceres, Bucharest.

Giannetti BF, Barrella FA, Almeida CMVB (2006). A combined tool for environmental scientists and decision makers: ternary diagrams and emergy accounting. J Clean Prod 14:201-210.

Giannetti BF, Almeida CMVB, Agostinho F, Bonilla SH, Ulgiati $S$ (2013). Primary evidences on robustness of environmental accounting from emergy. J Environ Acc Manag 1(2):203-212.

Herrera CM, Perez R, Alonso C (2006). Extreme intraplant variation in nectar sugar composition in an insect-pollinated perennial herb. Am J Bot 93(4):575-581.

Laurenson S, Houlbrooke D (2012). Review of guidelines for the management of winery wastewater and grape marc. Report prepared for Marlborough District Council.

Leoni S, Madeddu B (1992). The use of marc as a substrate for tomato cultivation in greenhouses. Colture Prot 21(6):67-71.

Olle M, Ngouajio M, Siomos A (2012). Vegetable quality and productivity as influenced by growing medium: a review. Agriculture 99(4):399-408.

Parent SE, Parent LE, Rozanne DE, Hernandez A, Natale W (2013). Nutrient balance as paradigm of soil and plant chemometrics. InTech 83-114. http://dx.doi.org/10.5772/ 53343.

Restrepo AP, Medina E, Perez-Espinosa A, Agullo E, Bustamante MA, Mininni C, Bernal MP, Moral R (2013). Substitution of peat in horticultural seedlings: suitability of digestate-derived compost from cattle manure and maize silage codigestion. Commun Soil Sci Plan 44:668-677.

Santiago A, Santiago L (1989). Charcoal chips as a practical substrate for container horticulture in the humid tropics. Acta Hort 238:141-148.

Shi ZJ, Lu Y, Xu ZG, Fu SL (2008). Enzyme activities of urban soils under different land use in the Shenzhen city, China. Plant Soil Environ 54(8):341-346.

Thomas W (1938). Foliar diagnosis: its relation to the optimum nutrition of the potato. Plant Physiol 13(4):677-694.

Watanabe A, Kuwatsuka S (1991). Triangular diagram for humus composition in various types of soils. Soil Sci Plant Nutr 37(1):167-170. 